\title{
Z idiograficzności zmagań z twórczością Andrzeja Stasiuka
}

DOI: 10.19195/2083-7763.7.13

Kim jest dla mnie Andrzej Stasiuk, czym zaś są jego książki? Jaką wartość dla badacza zorientowanego na mechanizmy analizy dokumentów osobistych może mieć ta twórczość? Dlaczego w ogóle warto ją ujmować w ramach rzeczonej procedury badawczej? Wokół tych pytań będzie ogniskować się wywód, mający - co należy podkreślić już na wstępie - charakter przywołania tego, co organizowało moje podejście do wspomnianego pisarstwa. Rekonstrukcje zaś, jak wiadomo, obciążone są wieloma negatywnymi atrybutami: wybiórczością pamięci narratora, nierzadko podejmowanymi przezeń (świadomie lub nie) zabiegami autopromocyjnymi, dokonywanymi ex post próbami racjonalizacji swych niegdysiejszych myśli i działań. Należy zadeklarować gotowość do omijania tego typu pokus, trudno jednak stwierdzić, na ile zabieg ten okaże się skuteczny.

Proponując jeden ze sposobów, w jakie nauki społeczne mogą podchodzić do dzieła literackiego, umieszczam poniższe rozważania w obrębie zainteresowań socjologii literatury. W związku z tym wynotujmy za Grzegorzem Jankowiczem i Michałem Tabaczyńskim dwa spośród zarzutów formułowanych pod adresem tej subdyscypliny.

Socjologia literatury zagraża samej literaturze - jej rozwojowi i pozycji, jaką działalność literacka zajmuje w obrębie całej kultury — gdyż niszczy naszą wiarę w metafizyczną moc sztuki. [...] Socjologowie literatury przekonują nas, że potrafią uchwycić i opisać relacje między sferą społeczną a literaturą, w rzeczywistości jednak tworzą zaledwie pozór naukowości, który z łatwością można zdemaskować za pomocą innych narzędzi krytycznych ${ }^{1}$.

${ }^{1}$ G. Jankowicz, M. Tabaczyński, Socjologia literatury jako nieodzowne źródło cierpień, [w:] Socjologia literatury. Antologia, red. G. Jankowicz, M. Tabaczyński, Kraków 2015, s. 10. 
Gdyby wyłuskać istotę tych opinii, do wspomnianej obawy związanej z „pokusą autopromocji” sugerują one dołączyć inne niebezpieczeństwo: analizujący dzieło literackie socjolog, nie dość, że odziera je z owego nimbu metafizyki, to jeszcze - czasem - nie jest w stanie sprostać postawionemu sobie przez siebie wyzwaniu.

Zarazem jednak autorzy tych słów, redagując antologię tekstów poświęconych socjologii literatury, wydają się podzielać przeświadczenie o niejakiej przydatności tej dziedziny wiedzy. Wtórując temu przekonaniu, ale i zachowując świadomość czyhających na badacza pułapek, warto przytoczyć słowa Wendy Griswold, która zachęca:

Ostatnie konflikty narodowe i etniczne sugerują nowe spojrzenie na stosunek pomiędzy literaturą a tożsamością. Konieczne są badania wzajemnego oddziaływania makrostruktur polityki językowej i transformacji formy rządów (regime transformation) z mikroprocesami czytania i konstruowania znaczenia oraz wpływu instytucji edukacyjnych i produkcji literackiej. Takie badania pomogą zrozumieć rolę literatury w trwającym procesie konstrukcji i podtrzymywania tożsamości - procesie, za który ludzie wciąż są gotowi oddać życie ${ }^{2}$.

Nawet jeśli optymistycznie założyć, że powyższe tezy w swej ostrości raczej nie odnoszą się do kontekstu Europy Środkowej, która przez lata stanowiła główny obiekt zainteresowania Andrzeja Stasiuka, to i tak wydają się mieć zastosowanie do tej twórczości i osoby jej autora. W tekstach tych znajdujemy bowiem tak wiele odniesień do „sfery etniczno-narodowościowej”, że przypuszczenie co do tego, iż inspirują one czytelników do zgłębiania rzeczonej materii, graniczy z pewnością.

\section{„Jestem idiotą, który opisuje to, co widzi”, czyli o założeniach artykułu}

Używając w tytule artykułu słowa „zmagania”, chciałem zaakcentować fakt, że Stasiukowe opowieści i opisy, choć jawią się jako dość „proste, łatwe i przyjemne", to jednak kryją w sobie coś znacznie głębszego. W tym duchu należy też rozumieć autokrytyczną deklarację pisarza: „jestem idiotą, który opisuje to, co widzi”, złożoną zresztą w opozycji do modelu pracy reporterskiej Ryszarda Kapuścińskiego ${ }^{3}$; wyrażając się w tej samej poetyce, można bowiem stwierdzić, że przypuszczalnie jednak idiota nie byłby w stanie skonstruować i zwerbalizować takich myśli, jak te zaproponowane przez omawianego tu prozaika.

2 W. Griswold, Najnowsze tendencje w dziedzinie socjologii literatury, [w:] Socjologia literatury. Antologia, s. 30.

3 Rosja: wielka depresja. Z Andrzejem Stasiukiem rozmawia Ireneusz Dańko, „Nowa Europa Wschodnia" 2009, nr 3-4, s. 100. 
Choć nie miejsce tu na klasyfikację Stasiukowego pisarstwa ze względu na formę wypowiedzi, to jednak - niezależnie od stanowiska, jakie zająłby w tym względzie on sam - o utworach tych można powiedzieć, że nierzadko przybierają charakter dziennika. Nie chodzi tu jedynie o warstwę wierzchnią, a więc o fakt, że słowo „dziennik” pojawiło się w tytułach dwóch ważnych tekstów tego pisarza, nadając im walor dokumentów osobistych ${ }^{4}$ (tym bardziej że akurat bardziej adekwatny wydaje się tam termin „pamiętnik”, ewentualnie „nieregularnik”). Rzecz raczej w sposobie prowadzenia narracji, w której autor zdaje relację z tego, co zobaczył, przywołuje towarzyszące temu emocje i uruchamia wyobraźnię, oraz w tym, że o tej części swej prozy, która odnosi się do Wschodu, mówi, iż jest ona „[c]zymś pomiędzy moją autobiografią, wiejsko-podlasko-mazowiecką historią mojej rodziny, historią komunizmu i geografią Wschodu" 5 .

Cytat, w którym Stasiuk mówi o sobie per „idiota”, przywołałem jednak przede wszystkim po to, aby pokazać sposób, w jaki sam pisarz swego czasu podchodził do własnej twórczości. Słowa te nie tylko bowiem zaznaczają rangę, jaką nadaje on swym obserwacjom, lecz także zaświadczają o tym, że dominującym (o ile nie wyłącznym) fundamentem tej twórczości jest subiektywizm narratora. Wprawdzie twórczość beskidzkiego pisarza w niejednym miejscu jawi się jako literackie ujęcie przeszłości, a do pracy nad niejedną książką przystępował wyposażony w wiedzę płynącą ze stosownych lektur, to jednak zjawiskiem, które książkom tym nadaje swoisty stempel oryginalności, jest wspomniany subiektywizm: wyobrażenia, projekcje i wariacje prozaika na temat odwiedzanych miejsc. Pamiętając zaś, że poczynione przy tych okazjach notatki są wyrazem tego, co pisarz zaobserwował, co go zainteresowało, zdziwiło czy wzruszyło, można przyjąć, iż zastosowana przezeń procedura pozwala analizować tę twórczość w duchu autoetnografii.

Korzyści płynące z przyjęcia tego podejścia w niniejszych rozważaniach ujawniają się przede wszystkim w możliwości określenia miejsca badacza w całym procesie interpretacji twórczości Stasiuka. Po pierwsze, mógłbym więc podpisać się pod stwierdzeniem "jestem idiotą, który opisuje to, co widzi”, ponieważ oddaje ono również moje własne niedostatki - jako interpretatora tego pisarstwa. Nie dysponując jednak narzędziami analitycznymi stosowanymi przez krytyków literackich, a także pamiętając o pułapkach, jakie czyhają na socjologa literatury, $\mathrm{w}$ artykule ograniczam się do przybliżenia sposobów, w jakie na potrzeby własnych dociekań próbowałem odczytywać tę twórczość. Formułując zatem nader minimalistyczne oczekiwania wobec idiograficzności - a więc ignorując pożytki

4 A. Stasiuk, Dziennik okrętowy, [w:] J. Andruchowycz, A. Stasiuk, Moja Europa. Dwa eseje o Europie zwanej Środkowa, Wołowiec 2001; idem, Dziennik pisany później, Wołowiec 2010.

5 Życie to jednak strata jest. Andrzej Stasiuk w rozmowach z Dorotą Wodecką, WarszawaWołowiec 2015, s. 38. 
kojarzone ze stosowaniem tego podejścia - mógłbym warunkowo zgodzić się ze stwierdzeniem, że w prezentowanym przypadku idiograficzność równa się niemożności wykrywania prawidłowości ogólnych ${ }^{6}$.

Po drugie, przyjmując, że rozważania te zostały poczynione na gruncie (wywodzącej się z antropologii) autoetnografii, w ramach której zakłada się, iż to rezultaty rozpoznania indywidualnego doświadczenia badacza są kluczem do opisu interesującej go rzeczywistości (autoetnografia jako „narracja o sobie”7) - do niniejszego artykułu można podejść w sposób odmienny. W tym sensie istota wspomnianej idiograficzności - mój własny subiektywizm w odczytywaniu Stasiukowej prozy - staje się zaletą: jeśli bowiem, jak przekonuje Peter Collins, antropologia jest częściowo osadzona w refleksyjności (reflexivity), wówczas „ja narracyjne” (self), jako czynnik sprawczy owej zwrotności myślowej, musi być równie integralną częścią uprawiania antropologii ${ }^{8}$. Założenie to, rzecz jasna, ma pewne ograniczenia związane z bardziej ogólnym poglądem na sposób prowadzenia działalności naukowej. Jak bowiem pisze Heewon Chang, chociaż wielu antropologów umiejscowiło swoje prywatne opowieści w centrum własnych badań, to jednak autoetnografia, wzmacniając pozycję badaczy akceptujących subiektywność, lokuje się w opozycji do tych podejść, które opierają się na systematycznym przestrzeganiu procedur, a więc tego, co charakteryzuje pozycje obiektywistów 9 .

Domykając wątek autoetnograficzny, wypada wspomnieć, że w prezentowanym przypadku autorefleksyjność badacza (a więc moja własna) zasadza się na trzech filarach: doświadczaniu twórczości Stasiuka jako przykładu literatury pięknej, świadomości stosowanych przez siebie procedur analitycznych oraz wglądu w samego siebie jako „podróżnika” czy „badacza terenowego”, którego aktywność, a także jej charakter, są inspirowane i modelowane tą twórczością. Ten ostatni punkt jest zadośćuczynieniem przeświadczeniu Floriana Znanieckiego, że

jedynym sposobem, by rzeczywiście bezpośrednio doświadczyć systemu społecznego, jest wzięcie czynnego udziału w jego konstrukcji, tylko dzięki temu możemy bowiem być bezpośrednio świadomi dążności zaangażowanych w jego strukturę i faktycznej istotności wartości bezpośrednio uwzględnionych $\mathrm{w}$ jego składzie ${ }^{10}$.

Słowo komentarza wypada poświęcić także współczynnikowi humanistycznemu jako dyrektywie metodologicznej, po którą sięga wielu jakościowych badaczy dokumentów osobistych. O ile w sytuacji, gdy autorem tekstu jest „zwykły” narrator, osoba jednaz wielu, pożytkipłynące zzastosowania tego postulatu sąnader

${ }^{6}$ Zob. W.J. Paluchowski, Spór metodologiczny czy spór koncepcji - próba podsumowania, „Roczniki Psychologiczne” 2010, nr 1, s. 117-118.

7 M. Angrosino, Badania etnograficzne i obserwacyjne, Warszawa 2010, s. 147.

8 P. Collins, The self as resource?, [w:] The Ethnographic Self as Resource. Writing Memory and Experience into Ethnography, red. P. Collins, A. Gallinat, New York-Oxford 2010, s. 235.

9 H. Chang, Autoethnography as Method, Walnut Creek 2008, s. 45.

10 F. Znaniecki, Metoda socjologii, Warszawa 2008, s. 186. 
oczywiste, o tyle proza Andrzeja Stasiuka stanowi dla badacza poważniejsze wyzwanie. Mamy tu bowiem do czynienia nie tylko z zapisem oryginalnych doświadczeń pisarza, lecz także z nietuzinkowymi kompetencjami (m.in. podejmowaniem szczególnej tematyki, zdolnością do poczynienia interesujących obserwacji, umiejętnością ubrania ich w atrakcyjną formę językową itp.), które wśród części publiczności odbiór tego pisarstwa czynią wyjątkowym. O ile bowiem dokumenty pisane przez „zwykłych” narratorów badacz analizuje przez pryzmat założenia o subiektywistycznym ujmowaniu rzeczywistości społecznej - i to właśnie ono stanowi wówczas o głównym walorze interpretacyjnym tych materiałów - o tyle w przypadku tekstów Stasiuka (i innych literatów) warto pójść krok dalej. Wypada przyjąć, że częściej niż w „zwyczajnych” narracjach będziemy mieć do czynienia z obserwacjami, których ranga sięga poza perspektywę potoczną, jednostkową - i to niezależnie od tego, iż sam pisarz wielokrotnie odrzucał myśl, aby jego przemyślenia miały aspirować do miana jakiejś odmiany literatury faktu bądź wiedzy eksperckiej ${ }^{11}$. Przyjmując zatem założenie o społecznej nośności twórczości pisarza $\mathrm{z}$ Wołowca, szerzej wyłożone w innym miejscu ${ }^{12}$, uzasadnione wydaje się stwierdzenie, że analizowany przypadek wykracza poza to, co stanowi istotę współczynnika humanistycznego, i wymaga od badacza, aby sięgnął „wyżej”, „dalej" niż to, co oferuje mu owe podejście. Ujmując rzecz w formie mniej restrykcyjnej, można powiedzieć, że współczynnik humanistyczny to „za mało”, aby w pełni ogarnąć i docenić bogactwo oraz rangę treści, które Stasiuk pomieścił na kartach swych książek.

Niezależnie od rzeczonej nietuzinkowości, analizując teksty literackie, należy pamiętać o pokusie swego rodzaju autopromocji, której ulega niejeden twórca. Ma to znaczenie o tyle, że również teksty Stasiuka można - choćby za sprawą jego delikatnej sugestii (o czym poniżej) - traktować jako niepozbawione autobiograficznego rysu zapiski bacznego obserwatora i komentatora rzeczywistości. Jak pisze Jan Szczepański, problem z biografiami ludzi o szczególnym potencjale intelektualnym polega na tym, że czasami odzwierciedlają one nie tyle ich realny życiorys, ile sposób selekcji własnych doświadczeń ${ }^{13}$, skutkiem czego narrator, kierując się dbałością o swój wizerunek, może ulec pokusie zafałszowywania własnych przeżyć. Co więcej, jak wskazują Wojciech Doliński i Jerzy Żurko, nie można wykluczyć sytuacji, w której samo wyobrażenie odbiorcy (na przykład czytelnika) „wystarczy, by uruchomić refleksję o tym, że pisze się pamiętnik czy dziennik dla kogoś i w określonym celu, a powstający zbiór wspomnień, jako autonomiczne dzieło, będzie później »żyło« swoim życiem już

11 Jak deklaruje Stasiuk: „Nie jestem żadnym specjalistą [od Europy Środkowo-Wschodniej]. Nie zajmuję się reportażami, których zresztą nie czytam, bo mnie nudzą. W nich jest tak zwana „prawda", która mnie zupełnie nie interesuje. Kłamstwa są ciekawsze”; Życie..., s. 148.

12 Zob. M. Dębicki, Rosja w obserwacjach i projekcjach Andrzeja Stasiuka, [w:] Sąsiedztwa III RP - Rosja. Zagadnienia społeczne, red. M. Dębicki, J. Makaro, Wrocław 2016, s. 319-323.

13 J. Szczepański, Odmiany czasu teraźniejszego, Warszawa 1971, s. 605. 
niezależnie od intencji autora" ${ }^{14}$. Celem ilustracji można tu wspomnieć sytuacje, w których pisarz, żądny sukcesu (na przykład rynkowego), czasem też pozostając pod presją wydawnictwa, za wszelką cenę stara się trafić w gusta odbiorców swej twórczości.

Mając na względzie to niebezpieczeństwo, wypada podkreślić, że w przypadku ludzi sztuki, w tym literatury adresowanej do relatywnie wąskiego kręgu odbiorców (a tak właśnie, mimo niemałego sukcesu rynkowego, można ująć grono czytelników prozy Stasiuka) ryzyko to wydaje się mniejsze z uwagi na typową dla niejednego twórcy przekorę i ekstrawagancję, a także ze względu na prawo do artystycznej kreacji i prowokacji, skądinąd niełatwych w odbiorze, a więc zawężających grono odbiorców tej prozy. Co zaś tyczy się samego Stasiuka, warto dodać, że akurat opowieści o Rosji (a także teksty poświęcone rzeczywistości środkowoeuropejskiej, które wychodziły spod pióra pisarza wówczas jeszcze zdecydowanie mniej znanego) idą w poprzek nurtu, z jakim w kontekście tego państwa zwykle spotykamy się w Polsce, czego świadomość zachowuje również sam prozaik, gdy przestrzega: „Proszę tylko rusofila ze mnie nie robić, dlatego że przełamuję narrację wzgardy i agresji [wobec Rosji]" ${ }^{15}$. To powiedziawszy, należy jednak także przywołać opinię Marcina Czerwińskiego, który w kontekście jednego z dzieł Witolda Gombrowicza - twórcy z pewnością bezkompromisowego i językowo wymagającego - posłużył się dość wymownymi wyrażeniami „projekt artystyczny”, „sfingować" i „kreacja” ${ }^{16}$, oddalającymi od jednoznaczności analizowaną przeze mnie kwestię.

$\mathrm{Na}$ koniec tej części powinienem wytłumaczyć się ze stylu, jaki przyjąłem do organizacji niniejszych rozważań, niejednokrotnie być może kojarzącymi się $\mathrm{z}$ esejem naukowym. Otóż decydując się na tę formę ekspresji, zamierzam połączyć cechy eseju, wśród których, za Marianem Surmaczyńskim, wyróżniam między innymi duży ładunek subiektywizmu, niestronienie od odczuć czy elementy autobiograficzne jako ilustracje przedstawianych tez, z elementami naukowości, wszakże $\mathrm{w}$ artykule nie rezygnuję $\mathrm{z}$ aparatury naukowej (przypisów, cytatów), nie ograniczam rozmiaru swego wywodu, jak również nie dążę za wszelką cenę do lekkości stylu wypowiedzi ${ }^{17}$. W odniesieniu do tej ostatniej kwestii należy zatem podkreślić, że chociaż nie chodzi tu o kopiowanie fraz charakterystycznych Stasiukowemu pisarstwu, to jednak starając się oddać nastrój tej prozy, niejednokrotnie podejmowałem próbę wpisania się w tę poetykę.

14 W. Doliński, J. Żurko, Wybrane problemy statusu poznawczego tekstów pisanych - wprowadzenie, [w:] Rzeczywistość i zapis. Problemy badania tekstów w naukach społecznych i humanistycznych, red. W. Doliński et al., Łódź 2016, s. 16.

15 Życie..., s. 124.

16 M. Czerwiński, Odwzorowując autobiografię w sąsiedztwie biofikcji. O literackich kontekstach „Kronosu” Witolda Gombrowicza jako zapisków intymnych, [w:] Rzeczywistość..., s. 89.

17 M. Surmaczyński, Warsztaty metodologiczne doktorantów socjologii (Podręcznik), Wrocław 2002, s. 211-212. 


\section{Zbliżenia pierwsze i drugie, czyli wprowadzenie do ekshibicji}

Moja przygoda z twórczością Andrzeja Stasiuka rozpoczęła się jesienią 2005 roku, gdy jego książka Jadąc do Babadag (2004) została uhonorowana literacką nagrodą Nike, któremu to zdarzeniu towarzyszył szereg publikacji prasowych przybliżających autora i jego pisarstwo. Tym, co ujęło mnie w nich szczególnie, było zwrócenie uwagi na opisywane przez Stasiuka miejsca (najogólniej - rejonu Europy Środkowo- i Południowo-Wschodniej), a także rodzaj odbywanej przez pisarza wędrówki - niespiesznej, zorientowanej na smakowanie lokalnej rzeczywistości w jej rozmaitych odcieniach, zatrzymywanie się przy tematach nie tylko „mało literackich”, lecz także niemieszczących się w głównym nurcie tego, co współczesny człowiek zwykł uważać za godne uwagi.

Wspomniane materiały sprawiły, że postanowiłem poważniej zainteresować się pisarzem, który poruszał się po tych samych rewirach, co ja. Nie chodziło tu o rozmach podróży - jako wędrowiec o nader skąpym doświadczeniu bywania w krajach „tej innej Europy” ze Stasiukiem nijak nie mogłem się równać - lecz o atmosferę, która go inspirowała. Nie bez znaczenia był tu choćby fakt, że Stasiuk mieszka w Beskidzie Niskim - paśmie przywodzącym na myśl ten szczególny pejzaż: kulturowy, szkicowany historią, którego atrybuty spotykają się w słowie „pustka”, i przyrodniczy, symbolizowany przez brak spektakularności. Wtedy, kilkanaście lat temu, góry były mi już szczególnie bliskie, tak więc zaryzykuję twierdzenie, że to właśnie zapoznawszy się z książkami Stasiuka, podczas wyjazdów zacząłem intensywniej penetrować także tereny nizinne, poszukiwać nieco innych (społeczno-kulturowych) doznań, i - co najważniejsze - częściej decydować się na wyjazdy w miejsca, w których będzie możliwe uchwycenie ducha twórczości pisarza z Wołowca.

Równocześnie należy zaznaczyć, że wciąż po dziś dzień moje bezpośrednie, a więc niezapośredniczone przez media czy książki, doświadczenia ze Stasiukiem ograniczają się do uczestnictwa w jednym spotkaniu autorskim. Po jego zakończeniu, towarzysząc pisarzowi przez kilka kroków, miałem okazję zadać mu na osobności pytanie, na które otrzymałem odpowiedź niezwykle oszczędną, wyrażoną w formie, która zniechęciła mnie do kontynuacji rozmowy. Należy dodać, że nigdy też nie odwiedziłem Stasiukowych włości - Wołowca, Czarnego czy okolicznych wsi. Jak sądzę, okoliczności te są jedną z istotnych zmiennych warunkujących mój indywidualny odbiór tej prozy, a także sądów o charakterze publicystycznym, wyrażanych przez beskidzkiego prozaika.

Jeśli chodzi o echa samego pisarstwa, Jadąc do Babadag okazało się książką nader intrygującą, po raz pierwszy prowokując mnie do tego, aby robić notatki także z literatury nienaukowej. Początkowo były to głównie frazy inspirujące bardziej artystycznie niż socjologicznie, migawki z życia codziennego, które - jak się okazywało - też mogły aspirować do miana literatury pięknej, niż kreślone $\mathrm{z}$ większym rozmachem portrety tej czy innej zbiorowości; raczej 
wyłuskiwanie detalu niźli poszukiwanie historiozoficznych ujęć odwiedzanej części Europy. Była w tym również wspomniana już fascynacja pomysłem przybywania do "miejsc nieoczywistych”, o których mówi się, że „nic w nich nie ma”, a także wyrosłe na tej glebie pragnienie realizowania podobnych wyjazdów jeżdżenia trochę „bez celu”, snucia refleksji nad tym, co wyparte z powszechnej wrażliwości, pławienia się w zapamiętanych obrazach. Tę Stasiukową motywację dobrze oddaje taka oto scena $\mathrm{z}$ odwiedzonej przezeń głębokiej węgierskiej prowincji: „W Göncruszka chodniki były fioletowe od śliwek. Nad owocami unosiły się roje os i wokół ani śladu żywej duszy. Szliśmy przez wieś, a z podwórek nie dobiegał żaden dźwięk"18.

Podobne odczucia towarzyszyły mi także przy lekturze innego zbioru Stasiuka - Fado (2006) - który zapoczątkował etap czytania kolejnych dzieł pisarza natychmiast po ich ukazaniu się. Podobnie więc było z książką Dojczland (2007), poświęconą - jak wskazuje tytuł - naszym zachodnim sąsiadom, której wartości nie rozpoznałem jednak przy pierwszym do niej podejściu, wykazując przy lekturze nawet pewnego rodzaju irytację, że rzecz dotyczy tego właśnie państwa i społeczeństwa, nie zaś środkowej bądź południowo-wschodniej części Europy. Jeszcze mniejsze wrażenie zrobiła na mnie powieść Taksim (2009), w której, ignorując fabułę, poszukiwałem treści społeczno-kulturowych na temat miejsc akcji. To zresztą dość typowa cecha mojego odbioru Stasiukowej prozy; swego czasu powątpiewałem nawet, czy byłbym w stanie fascynować się nią, gdyby przybrała charakter bardziej fabularny, a przedmiotem rozważań byłyby, powiedzmy, Rosja, Chiny bądź Stany Zjednoczone.

Opisany etap zgłębiania tego pisarstwa można nazwać „okresem niewinności", gdyż cechował się on całkowitą otwartością na literackie propozycje Stasiuka - język, tematykę czy geografię - i ich niemal bezkrytyczną fascynacją. W tym miejscu wypada więc zapytać: czy właściwa dla owej fazy „niewinnego” odczytywania twórczości pisarza z Wołowca otwartość (tak zresztą pożądana przez niektórych analityków jakościowych jako korelat gotowości do wyzbycia się przez badacza jego uprzednich nastawień, z góry wyrobionych opinii) nie staje się przeszkodą, gdy dochodzi do interpretacji materiału, którą powinna cechować odpowiednia doza krytycyzmu?

\section{Snując się wewnątrz obwodu, czyli zgłębianie Stasiuka}

Trudno stwierdzić, jak bardzo rzeczona jednostronność naznaczyła mój odbiór Stasiukowej prozy. Na pewno należy jednak wspomnieć o doświadczeniu niemalże formacyjnym, jakim stała się dla mnie lektura eseju Dziennik okrętowy - swoistego środkowoeuropejskiego manifestu pisarza. Z tego tekstu pochodzi

18 A. Stasiuk, Jadąc do Babadag, Wołowiec 2004, s. 72. 
słynny fragment, w którym wymienia on miasta mieszczące się w trzystukilometrowym kręgu między Wołowcem a Warszawą (miejsce urodzenia Stasiuka). „Linia biegnie mniej więcej przez Brześć, Równe, Czerniowce, Kluż-Napoka, Arad, Szeged, Budapeszt, Żylinę, Katowice, Częstochowę i kończy się tam, gdzie zaczyna, czyli w Warszawie". Systematyzując ten krąg, autor zauważa, że w jego wnętrzu „Nie ma Niemiec, nie ma Rosji - co przyjmuję z pewnym zdziwieniem, ale też z dyskretną atawistyczną ulgą"19. Mnogość i różnorodność miejsc pojawiających się na kartach Stasiukowej prozy — nierzadko dużo bardziej peryferyjnych niż przywołane powyżej - wynikająca z jej szczególnego nasycenia geografią, sprawiła, że przystępując do kolejnych lektur, sięgałem po atlas. Warto dodać, że konieczność odszukiwania na mapie miejsc nie najważniejszych $\mathrm{w}$ skali Węgier, Rumunii czy Ukrainy stanowiła dla mnie źródło pewnej przyjemności. Być może kluczowa była tu chęć, aby wraz z pisarzem wychodzić poza ramy swego kraju; aby - jak Stasiukowe nastawienie zwerbalizowała Dorota Heck - transgranicze „traktować jako przestrzeń codziennej egzystencji” ${ }^{20}$.

Konsekwencją tej skłonności stała się potrzeba uczestnictwa w tym świecie w sposób głębszy niż tylko przez lektury. Zmaterializowała się ona w formie włóczenia się po zakurzonych plenerach wschodnich Węgier, odkrywania nowych sensów podróży słowacką koleją po zdegradowanych szlakach ostatnich kategorii, przebijania się przez pancerz własnych uproszczeń i stereotypów narosłych wokół Cyganów, bardziej „rozumiejącego” spojrzenia na los mieszkańców zapomnianych wsi gdzieś w ukraińskich Gorganach czy częstszych prób uruchamiania wyobraźni - wszystko to zaś spowite pragnieniem wytropienia znanych literacko zapachów i smaków. Mowa tu na przykład o konieczności skosztowania osławionej körte palinki (węg. wódka gruszkowa; trunek ten najczęściej pojawiał się u Stasiuka właśnie w wersji węgierskiej) czy — w Wojwodinie — śliwkowej wersji napoju.

Szybko więc uzmysłowiłem sobie, że książek beskidzkiego pisarza nie czytam jak literaturę piękną, lecz jak swoiste skrzyżowanie reportażu, eseju i literackiej historiozofii Europy Środkowo-Wschodniej. Co więcej, pisarstwo to stało się zwornikiem dla kilku idei, które - jak się okazywało - były dla mnie ważne. Twórczość ta zaoferowała mi bowiem możliwość pogłębiania dotychczas istniejących zainteresowań (na przykład geografią polityczną) i „wydobycia na powierzchnię świadomości” pragnienia koncentrowania się właśnie na tej części Europy, a także stworzyła szansę na poznanie, a z czasem i praktykowanie innego niż dotychczasowy modelu turystyki i krajoznawstwa. W ramach tego ostatniego punktu mieści się między innymi rozpoznanie wartości podróży jako takiej, przesunięcie akcentu z kwestii takich jak zabytki na zagadnienia związane z pospolitą codziennością i rzeczywistością

19 A. Stasiuk, Dziennik okrętowy..., s. 77-78.

${ }^{20}$ D. Heck, Doświadczenie pogranicza polsko-ukraińskiego we współczesnej literaturze polskiej, [w:] Sąsiedztwa III RP - Ukraina. Zagadnienia społeczne, red. M. Dębicki, J. Makaro, Wrocław 2015, s. 141. 
mało spektakularnych miejsc, a więc na zjawiska, które - choć wydają się nie mieć w sobie nic intrygującego dla przybysza - pomagają pełniej poznać społeczno-kulturowy rys odwiedzanego obszaru. Innymi słowy, podczas kolejnych wyjazdów mniejsze znaczenie zacząłem przypisywać temu, co można nazwać programem stricte krajoznawczym, w większym stopniu koncentrując się na poszukiwaniu poznanych u Stasiuka treści. Co ważne, nie chodzi tu jednak o tzw. podążanie śladami pisarza (na przykład docieranie do tych samych wsi, lokali itp.), lecz o wyłuskiwanie z odwiedzanego otoczenia znanych motywów geograficznych czy kulturowych jako przyczynków do innego typu doświadczania owych miejsc.

Jeśli chodzi o naukowy walor tego rodzaju dociekań, można go odnaleźć w tym, że studia te sytuują się w sąsiedztwie przedmiotu zainteresowań antropologii codzienności, a także - zachowując właściwe proporcje - praktykowanej niegdyś socjografii lub znanej z niemieckiego obszaru językowego Landeskunde, a więc „,zintegrowanej naukowo działalności krajoznawczej”, zwanej też „naukowym krajoznawstwem"21. Wprowadzając element naukowości, należy zauważyć, że z czasem doświadczenia własnych peregrynacji i zapamiętane z nich sceny stały się dla mnie swoistym kryterium sprawdzalności tego, o czym pisał Stasiuk; niekiedy moja refleksja stawała się bardziej złożona, prowokując do zastanowienia, czy coś podobnego widział też ów pisarz, a jeśli tak, to jak się do tego odniósł. Słowem - przejawem bardziej dojrzałego odbioru Stasiukowych tez stały się ich pierwsze weryfikacje w terenie. Warto przypomnieć, że znaczenie owego „ja narracyjnego" jako pewnego zasobu dla pracy badawczej - zarówno terenowej, jak i studyjnej - lokuje się w ramach podejścia etnografii humanistycznej ${ }^{22}$.

Był to więc już moment, kiedy zacząłem zdawać sobie sprawę z tego, jak wiele uwagi poświęcam twórczości Stasiuka i jak często obrazy z jego prozy przychodzą mi na myśl w najróżniejszych sytuacjach. Jednocześnie dochodzące mnie głosy i odczucia innych osób względem jego książek pozostawiały mnie z poczuciem, że choć czytałem o wszystkim, co przewija się w rzeczonych opiniach, to jednak punkt widzenia prozaika nie jest $\mathrm{w}$ moim przypadku przepracowany $\mathrm{w}$ stopniu dostatecznym. Zacząłem zatem zadawać sobie pytania niemalże założycielskie dla kolejnej fazy zainteresowania tym pisarstwem: czego właściwie dowiadujemy się z tych tekstów? Na ile trafnie pisarz ten rozpoznaje mechanizmy funkcjonowania świata w owej „gorszej” części Europy? Czy przemyślenia Stasiuka można traktować jako raport z obserwacji uczestniczącej - niezależnie od jego przewidywanej niechęci wobec słowa „raport” i traktowania swych spostrzeżeń jako formy wiedzy?

21 J. Dębicki, L. Harc, Interdyscyplinarność albo zintegrowanie dyscyplin a historyczne badania regionalne (na przykładzie Ślaska), [w:] Mundus hominis - cywilizacja, kultura, natura. Wokół interdyscyplinarności badań historycznych, red. S. Rosik, P. Wiszewski, Wrocław 2006, s. 443.

22 P. Collins, op. cit., s. 242. 
Głębszy namysł nad tymi kwestiami rozpocząłem od lektury nieznanej mi dotychczas Dukli (1998) i świeżo wydanego Dziennika pisanego później (2010), a także książek, które jednak nie wydały mi się tu szczególnie pomocne Murów Hebronu (1992) i Przez rzekę (1997). Jednocześnie po raz drugi sięgnąłem po (wówczas już niemal klasyczne) Jadąc do Babadag oraz Fado, Dziennik okrętowy, Dojczland i kilka krótkich szkiców. Co ważne, przystępując do czytania wspomnianych tekstów, nie miałem jeszcze planu poświęcenia Stasiukowi własnych artykułów. Pomysł ten zrodził się pod wpływem uświadomienia sobie, że liczne notatki, które sporządzałem podczas tych lektur, niejednokrotnie zawierały już nie tylko barwne cytaty, ale także moje przemyślenia czy komentarze do obserwacji prozaika. Oznacza to, że po pierwszych dwóch etapach podejścia do tej twórczości - doświadczania Stasiukowej Europy jedynie przez literaturę i podejmowania inspirowanych nią wyjazdów - przyszedł czas na trzecią ,warstwę" analizy: konstruowanie własnego obrazu odwiedzanych miejsc jako konglomeratu pierwotnych wyobrażeń literackich, pierwszych własnych obserwacji i zapisków, jak również ich ponownego odnoszenia do „źródeł”. Z biegiem czasu etap ten ulegnie dalszej strukturyzacji rozbudowaniu i zwielokrotnieniu jako efektów następnych pobytów w terenie, dalszych lektur, kolejnych powrotów do „klasycznych” książek pisarza z Wołowca itp.; innymi słowy, rezultaty kolejnych lektur i doświadczeń własnych będą raz po raz przefiltrowywane same przez siebie. Zwieńczeniem całego procesu będzie zaś etap czwarty - próba utrwalenia własnych myśli i doznań sprowokowanych twórczością Stasiuka w postaci artykułów o peryferiach, Cyganach i Rosji.

\section{Peryferie, Cyganie i Rosja, czyli zmagania wyższego rzędu}

Patrząc na sprawę z metodologicznego punktu widzenia, tym, co w moich zapiskach było najważniejsze, to próba argumentacji na rzecz włączenia Stasiukowych obserwacji do naukowej analizy określonych wycinków rzeczywistości społeczno-kulturowej obszarów przezeń odwiedzanych, czyli zaświadczenie o ich pewnej epistemologicznej nośności. W związku z tym należało zneutralizować potencjalny zarzut, odwołujący się do swoistej geograficznej nonszalancji pisarza posługującego się figurą, którą można określić jako „nie-miejsce” bądź „wielomiejsce" - świadomie (lub nie) mieszającego lokalizacje, a nawet zmyślającego. Odnośnie do opisów środkowoeuropejskich peryferii - najpełniej wyłożonych w Jadac do Babadag - problemem jest niejednokrotnie pojawiające się stwierdzenie: „Tak było w..., po którym następowała wyliczanka różnych miejsc z tej części kontynentu, który to zabieg mógł prowokować do wrażenia całkowitej bezzasadności eksploracji jego utworów na przykład w duchu - wydawałoby się, że w tym miejscu szczególnie przydatnej - ekologii społecznej. Szkoła ta, jak przypomina Irena Machaj, akcentowała „zainteresowanie badaniem relacji między terytorium a zamieszkującą je społecznością oraz użytkowaniem przestrzeni 
w ścisłym związku z wytwarzanymi przez grupy standardami kulturowymi”23, tak więc w przypadku omawianej tu prozy trudno było przejść do porządku nad wyrażeniem uniemożliwiającym lokalizację miejsca, o którym się orzeka.

Jak się jednak wydaje, dylemat ten można rozwiązać, rezygnując z zamiaru stworzenia swego rodzaju socjologicznej monografii danej miejscowości na rzecz bardziej ogólnego ujęcia tej części kontynentu. Należy wówczas przyjąć, że Stasiukowa geograficzna dezynwoltura nie jest tu zabiegiem przypadkowym, lecz raczej skrywa następujące przesłanie: przywołane obrazy możesz, czytelniku, znaleźć w tak wielu miejscach opisywanego obszaru, że specyfikacja przestrzenna nie jest tu czymś koniecznym; to po prostu część rzeczywistości tych peryferii, swoisty duch Europy Środkowej ${ }^{24}$. To dlatego epistemologiczny wymiar analizy rzeczonych treści ująłem niegdyś następująco:

nawet jeśli prawdą jest, że charakterystykę odwiedzanych (albo i nieodwiedzanych...) przez siebie miejsc Stasiuk całkowicie zmyślił, że opisywanej rzeczywistości doświadczał [jak zarzucali mu niektórzy krytycy - M.D.] tylko z perspektywy „hotelu, dworca i księgarni” i że nie znał miejscowego języka - zrobił to w sposób tak bardzo sugestywny, ze znawstwem lub przynajmniej wysokiej próby intuicją, które są właściwe dla (a zarazem pożądane przez) dojrzałego badacza, iż obrazy te zasługują na uwagę przynajmniej jako socjologiczna hipoteza, do której oczywiście należy podejść z właściwą postępowaniu naukowemu ostrożnościąa ${ }^{25}$.

Nośność spostrzeżeń pisarza z Wołowca starałem się podnieść także inaczej - traktując go jako szczególnego rodzaju narratora w wywiadzie socjologicznym, jednego $\mathrm{z}$ liderów opinii na temat środkowoeuropejskości (nawet pamiętając o tym, że sam Stasiuk wielokrotnie odżegnywał się od przypisywanej mu roli znawcy tej krainy). Jak się wydaje, zgromadzona przez prozaika pokaźnych rozmiarów wiedza na temat w owym czasie dość niszowy - dotyczący specyficznego obszaru, sfer życia, a także rodzajów podejmowanej przez jednostki aktywności, zwykle niemieszczących się w ramach zainteresowań obserwatorów może być z powodzeniem wykorzystywana jako wiedza ekspercka, której wartość poznawcza w badaniach socjologicznych, choć z reguły niedoceniania, czasami jednak bywa dostrzegana ${ }^{26}$. Naturalnie, traktowanie pisarza jako specjalisty nie zmienia zasadniczego trybu postępowania z takim materiałem, który odczyty-

${ }^{23}$ I. Machaj, Pogranicze, [w:] Encyklopedia socjologii, t. 3, red. H. Domański et al., Warszawa 2000, s. 125.

${ }^{24}$ Należy dodać, że przedmiotem zainteresowania pisarza stała się również rzeczywistość Polski, co najlepiej ilustrują książki Opowieści galicyjskie, Dukla czy Zima. W zbiorach tych, a także w powstałym na podstawie Opowieści... filmie Wino truskawkowe, Stasiuk dostarcza potężną dawkę obserwacji o charakterze socjologicznym, skierowanych na rodzimą prowincję. Zawarte tam wątki, odzwierciedlające także sposób odczytywania tych obrazów, domagają się jednak odrębnej opowieści.

25 M. Dębicki, $Z$ wędrówek po „opłotkach Europy”. Społeczno-kulturowe oblicze peryferii w twórczości Andrzeja Stasiuka, „Kultura i Społeczeństwo” 2012, nr 1, s. 86.

${ }^{26}$ J.R. Stempień, W.A. Rostocki, Wywiady eksperckie i wywiady delfickie w socjologii - możliwości i konsekwencje wykorzystania. Przykłady doświadczeń badawczych, „Przegląd Socjologiczny” 2013, nr 1, s. 89-91. 
wany jest przez odniesienie obserwacji narratora do rzeczywistości, w związku z czym badacz winien w swej analizie zastosować „podejście miękkie”: pamiętać, że charakter wypowiedzi jest niedookreślony, ponieważ łączą się w nim fakt, wizja, artyzm czy nieusystematyzowana metodologicznie obserwacja.

$\mathrm{Z}$ inną sytuacją mamy do czynienia w kontekście Cyganów - zbiorowości, której Stasiukowa charakterystyka (styl życia, sposób patrzenia na świat itp.) stała się kolejnym przedmiotem moich rozważań. Różnica względem punktu poprzedniego (a także kolejnego) polega na tym, że w tym wypadku obserwacje pisarza dużo łatwiej jest skonfrontować $\mathrm{z}$ naukową wiedzą na temat owej zbiorowości, a przywoływane przezeń zdarzenia należy traktować w większym stopniu jako fakty niźli tylko wytwory wyobraźni. Jednocześnie warto pamiętać, że w swej literackiej charakterystyce Romów interesujący nas prozaik abstrahuje od kilku kwestii, które są kluczowe dla zrozumienia specyfiki tego etnosu' ${ }^{27}$. Jako że możliwe jest skonfrontowanie Stasiukowych tez dotyczących Cyganów z rzeczywistością, nabierają one waloru diagnozy publicystycznej, momentami zaś wręcz przepowiedni. Dobrą ilustrację stanowi tu passus, w którym pisarz stwierdza, że jedną z konsekwencji życia w „Europie bez granic” będą wędrówki Romów w poszukiwaniu lepszego miejsca do życia ${ }^{28}$; jak pamiętamy, przypuszczenie to na szerszą skalę spełniło się po przystąpieniu Rumunii i Bułgarii do Unii Europejskiej.

Jeszcze inne podejście zdecydowałem się obrać, analizując obrazy kreślone przez beskidzkiego pisarza w kontekście Rosji, głównie na kartach Wschodu. Przede wszystkim chodziło tu o uchwycenie ewolucji, jaką dostrzegłem w kwestii jego nastawienia wobec tego kraju (w tym do podróży po nim): od Rosji jako państwa, które (szczęśliwie) nie mieści się w granicach „Stasiukowej Europy”, po miejsce, które odwiedza się, aby dowiedzieć się czegoś o sobie samym, w tym o swej przeszłości ${ }^{29}$. Wyraźniejsze metodologiczne rysy można dostrzec w realizacji drugiego zamiaru, jaki przyświecał mojemu podejściu do powtórnej lektury Wschodu, a także kilku innych tekstów odnoszących się do tej problematyki. Mowa o konstrukcji swoistej „typologii rosyjskości”, a więc subiektywnie wyróżnionych wiązek tematycznych, za pomocą których pisarz przedstawił swoje odczucia względem dalekowschodniej Rosji ${ }^{30}$. Postępowanie badawcze obejmowało tu procedurę typową dla tego rodzaju analiz, która - jak pisał Jan Szczepański - polega „na zaklasyfikowaniu całego bogactwa rzeczywistości opisanej w życiorysach do kilku typów", wsparciem zaś była analiza egzemplifikacyjna, w ramach której stawiane hipotezy ilustruje się przykładami z autobiografii ${ }^{31}$.

27 M. Dębicki, Cyganie w obserwacjach Andrzeja Stasiuka. Głos w kwestii Europy wielokulturowej, [w:] Społeczeństwo wielokulturowe - nowe wyzwania i zagrożenia, red. M. Biernacka, K. Krzysztofek, A. Sadowski, Białystok 2012, s. 225-241.

28 A. Stasiuk, Jadąc do Babadag, s. 264-265.

29 M. Dębicki, Rosja..., s. 325-331.

${ }^{30}$ Ibidem, s. 331-346.

31 J. Szczepański, op. cit., s. 598-599. 
Dodatkowym wsparciem w odczytywaniu myśli i odczuć Stasiuka wobec Rosji był przywołany wcześniej zbiór wywiadów przeprowadzonych z autorem, Życie to jednak strata jest, który stanowi potwierdzenie tego, że odmalowywane przezeń obrazy nie były li tylko wyrazem jednorazowego przypływu określonych emocji czy stricte literackiej kreacji, lecz relatywnie trwałym odzwierciedleniem sposobu pojmowania tej ziemi i kultury. Założenia tego nie burzy pojawiające się podczas lektury wspomnianych wywiadów wrażenie, że Stasiuk, odpowiadając na pytania dziennikarki, po prostu odczytywał jej stosowną kwestię ze Wschodu ${ }^{32}$; chociaż z punktu widzenia uczciwości wobec czytelnika jest to posunięcie co najmniej dyskusyjne, to jednocześnie - metodologicznie rzecz ujmując - wzmacnia ono tezę o względnej trwałości poglądów pisarza. Należy zaznaczyć, że owa wielość źródeł poświęconych Wschodowi ${ }^{33}$ nie unieważnia podstawowego problemu, przed którym stanąłem jako badacz tych treści: w dwójnasób ujmowanej niemożności odniesienia obserwacji prozaika do własnego doświadczenia. Po pierwsze, chodzi tu o brak doświadczeń związanych z empiryczną znajomością rosyjskiego Dalekiego Wschodu, i po drugie - o nieumiejętność (na obecnym etapie?) wytworzenia owego specyficznego stanu umysłu, umożliwiającego spojrzenie na komunizm à la Stasiuk.

Interpretując Wschód, warto mieć na względzie także inne wyzwanie. Nigdy dotąd czytelnik nie otrzymał od Stasiuka tak obfitej porcji obserwacji na temat Rosji, w których jednak kraj ten miejscami jest niewiele więcej niż pretekstem czy inspiracją dla opowieści o kwestii nadrzędnej - indywidualnej (samego pisarza) i zbiorowej (ogółu Polaków) tożsamości, w tym miejsca, jakie zajmuje w niej pamięć o komunizmie. W tym sensie analiza myśli dotyczących Rosji natrafia na tę samą trudność, która towarzyszy interpretacjom wcześniejszych Stasiukowych obrazów, związaną z wykorzystywaniem przez prozaika wspomnianej figury „nie-miejsca” lub „wielomiejsca”. Zarazem jednak można tu dostrzec pewne różnice, z których pierwsza polega na tym, że - jak się wydaje - kiedyś pisarz epatował frazami typu: „Tak było w..., a może w...”, jakby z pogardy dla geograficznej precyzji i/lub wysiłków tych, którzy zapragnęliby ruszyć w podróż jego śladami, we Wschodzie zaś przywoływane lokalizacje wprost zestawiane są z miejscami z Podlasia czy wschodniego Mazowsza, tak więc czytelnik jasno widzi, że nie o Rosję czy Mongolię tu chodzi (a w każdym razie: nie przede wszystkim), lecz o bardziej uniwersalne wytwory wspomnianego czasu i systemu. Druga różnica dotyczy częstotliwości pojawiania się plenerów nadwiślańskich i nadbużańskich, która niegdyś (Jadąc do Babadag, Fado, Dziennik pisany później) była wyraźnie mniejsza niż w tekstach poświęconych Dalekiemu Wschodowi (choć

32 Por. na przykład fragment o załatwieniu pracy dla syna kierowcy wiozącego Stasiuka i jego towarzyszy podróży, brzmiący identycznie w dwóch analizowanych tekstach: Życie..., s. 135 i A. Stasiuk, Wschód, Wołowiec 2014, s. 146.

${ }^{33}$ Mówiąc o wielości źródeł, mam na myśli także inne, nieprzywołane w niniejszym artykule teksty Stasiuka, w których powracał on do nakreślonych przez siebie wizji tego kręgu cywilizacyjnego. 
i wtedy nie brakowało głosów, że Stasiuk, opisując cokolwiek, tak naprawdę ma przed oczami głównie Polskę). I po trzecie, terenowa weryfikacja trafności opisów poczynionych w Rosji napotyka poważny problem związany nie tylko ze wspomnianymi ograniczonymi możliwościami zorganizowania sobie przez wielu miłośników tej prozy wyjazdu do tej części świata, lecz także z faktem, że Sokołów Podlaski, Węgrów czy Siedlce trafiły na karty Wschodu w kształtach jakby wygrzebanych z pamięci dzieciństwa i wczesnej młodości pisarza, co oznacza, że w miejscowościach tych próżno by dziś szukać klimatu, który był pierwowzorem dla opisanych w książce dalekowschodnich krajobrazów przyrodniczych i kulturowych.

I jeszcze zdanie w kwestii mojego - jako badacza tej twórczości - „dorastania" do Rosji. Jak zaznaczyłem, pierwotnie nie przypuszczałem, aby teksty poświęcone temu państwu były mnie w stanie głębiej poruszyć, a jeśli już, to wyłącznie na zasadzie potwierdzenia, że tematyka ta jest mi obca. Dlaczego więc w tym przypadku - ale już nie w odniesieniu do Stanów Zjednoczonych, którym pisarz również poświęcił kilkanaście akapitów - stało się inaczej? Być może chodziło tu właśnie o ów komunizm jako nie całkiem mi obce doświadczenie, o nominalną słowiańskość (i w tym sensie bliskość) państwa i przekonanie o szczególnej pozycji zajmowanej przez Rosję w historii i kulturze Polski. Przekonanie, że to jednak jej sąsiad, nawet jeśli gdzieś w odległej Buriacji nigdy o Rzeczpospolitej nie słyszano; że - krótko mówiąc - chodzi tu o wspólnotę idei, których geografia nie zaciera, a jedynie nadaje im swoisty koloryt.

\section{Podsumowanie, czyli ogólniej o tym, co autor chciał powiedzieć}

Analizując charakter narracji Andrzeja Stasiuka w kontekście trzech wspomnianych zagadnień - peryferii, Cyganów i Rosji - można dostrzec, że choć wszystkie one przesiąknięte są subiektywizmem spojrzenia pisarza, to jednak każde posiada w tym ujęciu nieco odmienny status ontologiczny. W pierwszym przypadku mamy do czynienia z (do pewnego stopnia) zdeterytorializowaną ${ }^{34}$ literacką wizją Europy Środkowo-Wschodniej, opartą na intuicji i wyobraźni, choć także na odniesieniach do historiozofii tego regionu oraz jej współczesnych materializacji, odnajdywanych - także w Polsce - przede wszystkim na obszarach peryferyjnych. Równocześnie naturę owych obserwacji odnoszących się do czegoś, co nazwałem „wielomiejscem”, określa właściwy etnografii stosunkowo wysoki poziom dbałości o detal czy właśnie idiograficzność, której celem

${ }^{34} \mathrm{Na}$ kwestię deterytorializacji, w znaczeniu oderwania danego zjawiska od określonego kontekstu terytorialnego, zwracał uwagę Arjun Appadurai w swej książce Nowoczesność bez granic. Kulturowe wymiary globalizacji. Zastosowanie do fragmentów twórczości Stasiuka tej kategorii pozwala na teoretyczne ujęcie przeświadczenia, że natura niektórych zaobserwowanych przezeń zjawisk wykracza poza jasno określony obszar. 
jest ,sporząadzenie możliwie dokładnego opisu, dającego wgląd w strukturę i przebieg zjawisk" ${ }^{35}$. W formie etnografii, acz niewolnej od wątków publicystycznych czy wręcz profetycznych, przedstawiona jest także egzystencja Romów.

Jeśli chodzi o obrazy Dalekiego Wschodu, sprawą kluczową jest, że ich autor „podróżował w głąb samego siebie”, swych doświadczeń związanych z komunizmem i obecnością radzieckości w życiu swoim i swoich najbliższych. Czyni to $\mathrm{z}$ tej narracji konstrukcję mocno zsubiektywizowaną, dogłębnie przesiąkniętą idiograficznością w znaczeniu „braku powtarzalności zjawisk w najprostszym empirycznym (doznaniowym) sensie" 36 - a przynajmniej w sensie braku wymogu ich intersubiektywnej sprawdzalności. Oczywiście nie zmienia to faktu, że w warstwie przeżyć osoby, która wzorując się na przemyśleniach Stasiuka, zapragnie wyruszyć w podróż jego śladami, trudno jest wykluczyć reprodukcję pewnych obrazów zapoznanych we Wschodzie, toteż także w tym przypadku, analizując tego rodzaju sytuacje, należy mieć świadomość ich wtórnego (odtwórczego) charakteru, który rzecz całą każe widzieć raczej w optyce wywoływania czy wręcz zaklinania rzeczywistości przez miłośnika tej prozy, tak aby swym kształtem odpowiadała ona wyobrażeniom wyniesionym $\mathrm{z}$ lektur.

Warto powrócić jeszcze na moment do przypadku Stanów Zjednoczonych - dotychczas marginalnie obecnych w analizowanej tu twórczości. Casus ten może okazać się przydatny w kontekście kwestii zasygnalizowanej na początku artykułu: czy byłbym w stanie fascynować się tym pisarstwem - docenić Stasiukową frazę, lotność umysłu, niebanalność obserwacji, filozofię życia gdyby jego przedmiotem nie była Europa Środkowo-Wschodnia lub przynajmniej (jak w przypadku Wschodu) idee, które silnie naznaczyły jej tożsamość? W tym miejscu muszę przyznać, że nieco zląkłem się, czytając deklarację Stasiuka dotyczącą USA: „Podobał mi się ten kraj od pierwszego wejrzenia. Na lotnisku śmierdziało". Moje uczucie pogłębiło się, gdy pisarz wyznanie swe powtórzył, na dodatek ujmując je w ramy związku przyczynowo-skutkowego: „Podobał mi się ten kraj, ponieważ już na samym początku w nim śmierdziało", który myśli tej nadawał solidniejsze pozory realności i oddalał wrażenie spontaniczności. Czyżby więc - myślałem - Stany Zjednoczone miały stać się kolejną, nawet jeśli w porę nierozpoznaną, miłością pisarza? Pewien spokój przywrócił dopiero ostatni akapit cytowanego felietonu, pointujący doświadczenia z pobytu za oceanem: „Od razu wiedziałem, że to nie dla mnie. Trzeba mieć powód, żeby tu żyć”37.

Jako że powyższe wersy nawiązują do zasygnalizowanego wcześniej ekshibicjonizmu, warto przypomnieć, że tytułową idiograficzność moich zmagań

35 J. Szczepański, op. cit., s. 601.

36 W.J. Paluchowski, op. cit., s. 117.

37 Zob. A. Stasiuk, Manhattan, „Tygodnik Powszechny” 2015, nr 41. Jeśli chodzi o wizyty w USA, cenna jest też deklaracja złożona przez pisarza w stepie, gdzieś pod rosyjsko-mongolską granicą: „Wiedziałem, że nie wrócę na Manhattan. Nie wydam grosza ani nie poświęcę dnia, by się tam znaleźć"; idem, Wschód..., s. 180. 
z pisarstwem Andrzeja Stasiuka w sposób dosyć czytelny naświetla to, iż w analizach swych w zasadzie zupełnie abstrahuję od kontekstów ściśle krytycznoliterackich, koncentrując się w zamian na warstwie społeczno-kulturowej. Hołdując zaś przeświadczeniu o pewnej uniwersalności narzędzi socjologicznego poznania, można zaryzykować twierdzenie, że obrane przeze mnie podejście prawdopodobnie dałoby się zastosować także do analizy dzieł innych pisarzy, a więc że niekoniecznie jest ono tak bardzo wyłączające (idiograficzne), jak mógłby sugerować początek niniejszego artykułu. Być może znalazłby się badacz społeczny patrzący na twórczość Stasiuka podobnie jak ja, choć przecież równie dobrze przypuszczenie to może pozostać tylko pobożnym życzeniem.

\section{Bibliografia}

Angrosino M., Badania etnograficzne i obserwacyjne, Warszawa 2010.

Appadurai A., Nowoczesność bez granic. Kulturowe wymiary globalizacji, przeł. Z. Pucek, Kraków 2005. Chang H., Autoethnography as Method, Walnut Creek 2008.

Collins P., The self as resource?, [w:] The Ethnographic Self as Resource. Writing Memory and Experience into Ethnography, red. P. Collins, A. Gallinat, New York-Oxford 2010.

Czerwiński M., Odwzorowując autobiografie w sasiedztwie biofikcji. O literackich kontekstach "Kronosu” Witolda Gombrowicza jako zapisków intymnych, [w:] Rzeczywistość i zapis. Problemy badania tekstów $w$ naukach społecznych i humanistycznych, red. W. Doliński, J. Żurko, K. Grzeszkiewicz-Radulska, S. Męcfal, Łódź 2016.

Dębicki J., Harc L., Interdyscyplinarność albo zintegrowanie dyscyplin a historyczne badania regionalne (na przykładzie Śląska), [w:] Mundus hominis - cywilizacja, kultura, natura. Wokót interdyscyplinarności badań historycznych, red. S. Rosik, P. Wiszewski, Wrocław 2006.

Dębicki M., Cyganie w obserwacjach Andrzeja Stasiuka. Głos w kwestii Europy wielokulturowej, [w:] Społeczeństwo wielokulturowe - nowe wyzwania i zagrożenia, red. M. Biernacka, K. Krzysztofek, A. Sadowski, Białystok 2012.

Dębicki M., Rosja w obserwacjach i projekcjach Andrzeja Stasiuka, [w:] Sąsiedztwa III RP - Rosja. Zagadnienia społeczne, red. M. Dębicki, J. Makaro, Wrocław 2016.

Dębicki M., Z wędrówek po „opłotkach Europy”. Społeczno-kulturowe oblicze peryferii w twórczości Andrzeja Stasiuka, „Kultura i Społeczeństwo” 2012, nr 1.

Doliński W., Żurko J., Wybrane problemy statusu poznawczego tekstów pisanych - wprowadzenie, [w:] Rzeczywistość i zapis. Problemy badania tekstów w naukach społecznych i humanistycznych, red. W. Doliński, J. Żurko, K. Grzeszkiewicz-Radulska, S. Męcfal, Łódź 2016.

Griswold W., Najnowsze tendencje w dziedzinie socjologii literatury, [w:] Socjologia literatury. Antologia, red. G. Jankowicz, M. Tabaczyński, Kraków 2015.

Heck D., Doświadczenie pogranicza polsko-ukraińskiego we współczesnej literaturze polskiej, [w:] Sąsiedztwa III RP - Ukraina. Zagadnienia społeczne, red. M. Dębicki, J. Makaro, Wrocław 2015.

Jankowicz G., Tabaczyński M., Socjologia literatury jako nieodzowne źródło cierpień, [w:] Socjologia literatury. Antologia, red. G. Jankowicz, M. Tabaczyński, Kraków 2015.

Machaj I., Pogranicze, [w:] Encyklopedia socjologii, t. 3, red. H. Domański et al., Warszawa 2000.

Paluchowski W.J., Spór metodologiczny czy spór koncepcji - próba podsumowania, „Roczniki Psychologiczne" 2010, nr 1.

Rosja: wielka depresja. Z Andrzejem Stasiukiem rozmawia Ireneusz Dańko, „Nowa Europa Wschodnia" 2009, nr 3-4. 
Stasiuk A., Dziennik okrętowy, [w:] J. Andruchowycz, A. Stasiuk, Moja Europa. Dwa eseje o Europie zwanej Środkowa, Wołowiec 2001.

Stasiuk A., Dziennik pisany później, Wołowiec 2010.

Stasiuk A., Jadąc do Babadag, Wołowiec 2004.

Stasiuk A., Manhattan, „Tygodnik Powszechny” 2015, nr 41.

Stasiuk A., Wschód, Wołowiec 2014.

Stempień J.R., Rostocki W.A., Wywiady eksperckie i wywiady delfickie w socjologii - możliwości $i$ konsekwencje wykorzystania. Przykłady doświadczeń badawczych, „Przegląd Socjologiczny” 2013, nr 1 .

Surmaczyński M., Warsztaty metodologiczne doktorantów socjologii (Podręcznik), Wrocław 2002.

Szczepański J., Odmiany czasu teraźniejszego, Warszawa 1971.

Znaniecki F., Metoda socjologii, Warszawa 2008.

Życie to jednak strata jest. Andrzej Stasiuk w rozmowach z Dorotą Wodecką, Warszawa-Wołowiec 2015.

\section{On idiographism of the struggle with Andrzej Stasiuk's output}

\section{Summary}

The aim of the paper is to present a set of individual experience by the author of the article concerning the ways in which he has read out and interpreted the output of one of the most widely read contemporary Polish writer - Andrzej Stasiuk. The consideration is thus an attempt at recognizing and grasping one's own approach (that is the reason why idiographicity appears in the title) to Stasiuk's books; an attempt put within the frames of social sciences, treated here as theoretical-methodological background for these endeavors, as well as the researcher's individual travelling practices (obviously, filled with the writers' inspirations). At the crossing point of these phenomena there appeared my own consideration on this literature, and the reconstruction of its course as well as its results (in the form of some scientific publications concerning this prose) became the point of departure for the article. 